\title{
Is there a relation between capital and ownership on bank performance? The German and Italian cases
}

\section{Belinda Laura Del Gaudio* and Claudio Porzio}

Department of Management and Quantitative Studies, University of Naples Parthenope,

Via Generale Parisi, 13 Naples, 80133, Italy

Email: belindal.delgaudio@uniparthenope.it

Email: claudio.porzio@uniparthenope.it

*Corresponding author

\begin{abstract}
This paper examines the effects of capital on bank performance, considering the ownership structure using a large sample of German and Italian cooperative and commercial banks from 2006 to 2012. The determinants of performance are studied using a set of variables reflecting the bank's core business and bank-type characteristics, namely, total assets, dependency on funding and liquidity combined with capital and risk measures. The findings show that the ownership structure drives the impact of capital measures and liquidity on performance. The differences in the impact of capital strength among cooperatives and commercials could be derived from differences in capital formation and management. This paper includes implications for regulatory authorities, who should consider the latter in the definition of new regulatory sets.
\end{abstract}

Keywords: bank performance; cooperative banks; ownership; capital; business model.

Reference to this paper should be made as follows: Del Gaudio, B.L. and Porzio, C. (2018) 'Is there a relation between capital and ownership on bank performance? The German and Italian cases', Int. J. Governance and Financial Intermediation, Vol. 1, No. 1, pp.37-58.

Biographical notes: Belinda Laura Del Gaudio completed her $\mathrm{PhD}$ in Economics and Management at the Department of Management and Quantitative Studies of the Parthenope University of Naples. Prior to that, she conducted her studies in banking and finance at the Bocconi University and Università Cattolica del Sacro Cuore in Milan. She was also visiting at the Indian School of Business in Hyderabad. Her research interests concern on banking and finance with particular focus on bank governance and bank-firm relationship.

Claudio Porzio is the Dean of Department of Management and Quantitative Studies of the University of Studies of Naples Parthenope. He is a Professor of Economics of Financial Intermediaries at the University of Studies of Naples Parthenope. He is a member of professors committee of $\mathrm{PhD}$ in Banking and Finance at the University of Tor Vergata di Rome. He is a Full Professor of Insurance and Financial Intermediaries of SDA at the Bocconi University. He is a collaborator of the Centre for the Studies in Finance 'Carefin' at the Bocconi 
University. He is a member of the AIFIRM Risk Management Magazine Newsletter. He has participated, as a consultant, on study missions on behalf of FAO, the European Commission and CICA. He has consultancy and teaching activities on behalf of leading banking and financial institutions.

\section{Introduction}

This paper examines the cross effect between capital and ownership on bank performance, distinguishing banks' main characteristics using a large sample of German and Italian cooperative and commercial banks between 2006 and 2012. This paper examines two types of banks: cooperatives, which provide services mainly to their members, households and small and medium-sized enterprises (SMEs), and commercial banks, that is, privately owned banks that provide services to the general public and private firms. The determinants of performance are studied using a set of variables reflecting the bank's core business: total assets, dependency on funding and liquidity combined with capital and risk measures. The motivation of this research is that whereas the factors driving a bank's economic performance are generally not disputed, the way in which they reflect the underlying ownership structures is less clear and more controversial. In particular, the relation between capital and ownership structure may affect the process of income production by creating areas of diseconomies or inefficiencies which, in turn, affects performance.

The empirical literature on bank performance does not obtain unique results on the relation between performance and ownership structure. For instance, Iannotta et al. (2007) find evidence on the cost advantages of cooperative banks but not in terms of profit making, analysing large banks in 15 European countries. Ayadi et al. (2010) find that cooperatives exhibit comparable or slightly superior earnings compared to commercial banks in Germany, Italy and Spain. Cihák and Hesse (2007) find that cooperative banks are less profitable in terms of ROA and are less capitalised in terms of equity to total assets than are commercial peers. Ferri et al. (2015) find lower profitability and cost efficiency for stakeholder (STK) banks but not in terms of loan quality using a panel of Euro15 including the financial crisis year.

These majority of these studies focus on the performance of shareholder (SHV) and STK banks before the crisis, with no consensus in results. The heterogeneity of results probably depends on the different periods and countries analysed. In addition, several studies exploited the relation between performance and the ownership structure (represented in most of case by a dummy variable), but fewer explored the way that the ownership in turn affects performance. Lastly, the studies exploring the topic during the financial crisis are very limited.

Therefore, this paper will fill in these gaps. First, this study contributes to the literature, adding to the few studies that consider the financial crisis in the time span. Second, the study considers the way that ownership structure affects performance, particularly examining whether and how capital can affect performance in commercial 
and cooperative banks differently. With this point of view, to the best of my knowledge, this study is the first to attempt to exploit the cross effect between capital and ownership, also using regulatory measures. Capital exerts several effects on bank activity. In general, as Tahkor (2014) stresses, the effect of capital in not as immediate. Iannotta (2006) highlights that better capitalised banks may reflect higher management quality, thereby generating a positive coefficient on returns. In addition, as noted by Berger and Udell (1995), well-capitalised firms face lower expected bankruptcy costs which, in turn, reduce their cost of funding and increase their returns. Moreover, Mehran and Thakor (2011) find that a high level of capital induces banks to screen more intensively. A third interpretation relies on the effects of the Basel accord, requiring banks to hold a minimum level of capital as a percentage of risk-weighted assets. Higher levels of capital may therefore denote banks with riskier assets (Iannotta, 2006). This property is no longer observed for cooperatives that cannot 'screen more intensively' because they are compelled to a territoriality limit to their activity and cannot differentiate the risk, as they are compelled to supply a percentage of loans to their members.

Lastly, this study is the first to consider decentralised systems, namely, Italy and German, in the period in which the analysis is conduced instead of a macro region or a single country. In this way, the study considers the heterogeneity of the cooperative environment, which could lead to a biased interpretation of the results, as noted by Karafolas (2016). Considering countries with organisation in a centralised system which involves, among other things, the creation of a safety net and mechanism of liquidity redistribution could lead to results that are not directly comparable. The importance of analysing countries with similar organisation systems should not be undervalued because it can bias the interpretation of results. Cooperative banks, in turn, differ significantly in their degree of integration (Ferri et al., 2015). The different degree of integration should in turn affect bank activity and thus performance differently. For instance, organisation in the network provides liquidity, safety net and capital; these mechanisms can directly affect the risk-taking policy and the balance sheet of single bank. In addition, this approach allows us to have a wider database compared to single-country perspective.

This paper uses data information exported by Bankscope of Italian and German Banks over the period of 2006 to 2012. The study assesses the impact of bank-specific characteristics, such as liquidity, size and, in particular, the cross effect between capital and ownership on bank performance. The study uses the return on assets (ROA) as a performance measure because SHV and STK banks pursue different objective and goals.

The findings show that cooperative banks are less profitable in terms of ROA than are commercial banks during the period considered. Analysing the bank-specific characteristics which, in turn, affect performance, the results confirm the suspicion that capital has a different role for SHV and STK banks. In particular, when the model accounts for regulatory measures, capital has different impacts on performance for the two types of banks.

The paper is organised as follows. Section 2 reviews the papers that motivated the empirical specifications. Section 3 shows the sample selection strategy and describes the data used. Section 4 provides the discussion of the empirical design. Section 5 presents the results. Section 6 checks the robustness of the results, and Section 7 presents the study's conclusions. 


\section{Literature review and research hypotheses}

Ownership structure affects the process of production and allocation of income, as an element of corporate governance. According to Iannotta et al. (2007), the firm ownership structure is defined along two dimensions. First is the degree of ownership concentration, and second is the nature of owners. In the European banking industry, a tree type of structure exists, with privately owned stock banks, mutual banks, and government-owned banks. The ownership structure, as well as the aims and the objectives pursued by the firm, are the main elements that characterise the distinction between SHV and STK business models. In particular, the SHV model can be regarded as a business focused on profit maximisation for SHVs, whereas for STK, profit is one of the goals as part of generally maximising the consumer surplus for their owner members (Ayadi et al., 2010). The theoretical literature has highlighted the inefficiencies of the STK model in an agency theory view. The main arguments are summarised as adverse selection due to the principle of 'one head, one vote', no incentive for members to control derived from limited rights and low returns of member shares, no signal and price mechanism because of the absence of market discipline and absence of risk of take-over (see, e.g., Fonteyne, 2007). Further studies argue that agency theory does not explain well what occurs in the banking sector with reference to a regulated market characterised by the presence of a relationship between more than two subject (e.g., depositors, owners, managers, and authorities) and by the highly leveraged financial structure; market forces rarely play a role in the banking sector and competition is the more influent discipline for governance deficiencies. In addition, the empirical results are controversial and depend on the period of observation and on the country analysed (Adams and Mehran, 2003; Groeneveld and Llewellyn, 2011; Ayadi et al., 2010).

The empirical research investigated the performance of banks focusing particularly on both a single country and wide macro-regions (e.g., Europe). Valnek (1999), studying UK building societies over the period of 1983-1993, obtains evidence of better performance in terms of ROA compared to their commercial peers. In addition, Altunbas et al. (2001) evaluate the cost and profit efficiencies of different bank ownership forms operating in the German banking market between 1989 and 1996. These researchers find little evidence of more efficiency of privately owned bank compared with their counterparts. Private, public and mutual banks all appear to benefit from widespread economies of scale. Controlling for size, these authors find that for each ownership type, larger banks tend to realise greater economies. Inefficiency measures indicate that all sizes of public and mutual banks have slight cost and profit advantages over their private commercial banking counterparts, which can possibly be explained by their lower cost of funds. Stefancic and Kathitziotis (2011) evaluate the performance in terms of return on equity (ROE) of 60 commercial banks and 60 cooperative banks in Italy during the period of 2006 to 2009. Their results confirm that major differences exist in the business model of cooperative and commercial banks. Iannotta et al. (2007) investigate the difference in bank profitability and risks that depend on the ownership structure in the Euro-15 countries during the period of 1999 to 2004. These researchers test for systematic differences in bank performances measured by profit, earning and costs, with all being scaled for total earning assets between mutual banks, public sector banks and private banks, and banks with different ownership concentrations controlling for size, output mix, asset quality, country and year effects, and specific macroeconomic growth differentials. These researchers' findings confirm the existence of significant differences 
in performance and risk. In fact, they find evidence of the cost advantages of cooperative banks but not in terms of profit making. Ayadi et al. (2010) compare the profitability ${ }^{1}$, efficiency, market power and earning stability in several European countries ${ }^{2}$ between commercial, cooperative, and savings banks during the period of 2000 to 2008 . Comparing cooperative banks with other banks, these authors find that significant differences exist for all countries. In particular, cooperatives exhibit comparable or slightly superior earnings compared to commercial banks in Germany, Italy and Spain.

Ferri et al. (2015) study the impact of ownership structure on performance (in terms of profitability, loan quality, and cost efficiency) in European banking both prior to and during the recent crisis. The findings on SHV banks show better profitability before the crisis but not in terms of loan quality, with STK banks having higher loan quality before and during the crisis. These researchers also find a strong heterogeneity in performance between different STK ownership groups. With the exception of private savings banks, the profitability and loan quality of STK banks have improved relative to that of general SHV banks during the crisis years. Beltratti and Stulz (2009) investigate the possible determinants of bank performance, as measured by stock returns, during the crisis for a sample of banks with assets in excess of $\$ 50$ billion at the end of 2006 across the world. These researchers analyse if bank performance is related to bank-level governance, country-level governance, country-level regulation, and bank balance sheet and profitability characteristics before the crisis. The researchers observe that banks with more SHV-friendly boards performed worse during that period. In contrast, banks with more tier 1 capital, more deposits, and more loans performed better. Banks from countries with stronger capital supervision had higher returns, as well.

However, a lack of empirical evidence on the relationship between bank profitability, the ownership structure and capital within the European countries seems to remain. To this end, this paper extends the consolidated literature on the ownership structures of the European banking system considering the important regulatory innovations, such as the new Basel accord.

Therefore, focusing on the main characteristics of the cooperative model (such as the retention of profit to capital and the direct relationship between the deposits and the lending activity), the objective is to verify if there is a relation between these characteristics and bank performance. In particular, does capital have a different impact on performance for cooperative and commercial banks?

\section{Sample selection and data description}

The sample is obtained starting with banks in Bankscope $e^{3}$, choosing both commercial and cooperative banks in Italy and Germany. The choice of these countries is driven by the fact that the performance of their banking systems is strictly related to the ownership structure, as suggested by the results of the empirical literature (e.g., Ayadi et al., 2010). Moreover, this comparison is relevant, for the purpose of this research because the 'three pillar' German banking system has had no substantial changes in comparison to Italy, where the 1980s witnessed the process of demutualisation, which is still in place (Bülbül et al., 2013). In addition, cooperative banks are organised in a decentralised system (Di Salvo, 2002) in both countries in the period analysed. In contrast, in other 
European countries, such as in Netherlands or in France, cooperatives are organised in a centralised system.

The following types are excluded from the dataset:

- 'Banche popolari': we can consider them as cooperative banks in terms of legal form, but some rules are different, such as SHVs having to be a resident in the same region as the cooperative bank. As such, 'banche popolari' can be considered a hybrid form between a commercial bank and cooperative bank, and we can exclude them.

- 'Savings banks': there are no savings banks in Italy; therefore, we exclude them.

The period considers all years available in Bankscope from 2006 to 2012. To avoid any problems of duplication of information, only the unconsolidated balance sheet is taken into account because it is possible to have several sources of accounting information in Bankscope.

Following this research strategy, from the initial dataset, which consisted of 1,639 banks (in particular, 526 located in Italy and 1,113 located in Germany), the units of observation that have no observation in the years considered are dropped (199 Italian banks and 272 German ones). As such, the dataset consists of 1,419 banks (420 are located in Italy and 999 in Germany). More than $90 \%$ are cooperative banks, as shown in more detail in Table A1.

To derive the model, the following variables are considered to appraise the specifics of cooperative banks. The existing literature measures the bank performance of banks primarily in terms of cost efficiency (Mester, 1993; Esty, 1997) or returns (Valnek, 1999). Iannotta et al. (2007) consider different performance measures, such as profit, income, and costs; Westman (2009) adds a measure of SHV performance, the ROE. The choice is to use an indicator that reflects the ability of management to generate earnings focusing on the core business of banks. Therefore, the choice falls on ROA, which measures the ROA, excluding ROE, which measures the ROE, as the latter does not reflect cooperative governance principles. Specifically, the model assesses the impact of size (total assets) and the banks' dependency on deposits (deposits/total assets, which is dependency), which captures the composition of the liabilities such that a bank with more deposits will have more stable financing compared to one that relies more on markets. In terms of profitability, the results are not immediately determined because the model implies low interest cost, but it is costly in terms of requiring a branching network (Demirgüç-Kunt and Huizinga, 2010). On the asset side, the model considers the so-called 'deposits transformation' activity (loans/deposits, that is ltd_w) on performance. This ratio shows the relationship between comparatively illiquid assets (i.e., loans) and comparatively stable funding sources (i.e., deposits and other short-term funding), and it is considered a measure of liquidity. In particular, a higher ratio corresponds to lower liquidity. ${ }^{4}$ Among the determinants of bank performance, the strength of capital exerts a significant and positive role (e.g., Iannotta et al., 2007; Beltratti and Stulz, 2009). Diamond and Rajan (2001) establish that equity financing reduces the ability of creditors to exert market discipline, and Mehran and Thakor (2011) find that it induces banks to screen more intensively. However, increased capital under certain circumstances could be negative because it increases bank risk taking (Koehn and Santomero, 1980). In addition, bankers who are reluctant to increase capital to higher capital requirements argue against higher capital requirements on the grounds that doing 
so would have a chilling effect on bank profitability and lending, as well as on economic growth (Tahkor, 2014). Berger and Bouwman (2009) find that the effect of capital differs by bank size and is influenced also by time, i.e., crisis or normal time (Berger and Bouwman, 2013). Vander Vennet and Mergaerts (2016) find a negative relation between capital and profitability in both the short and long-run performance. Extensive literature uses the capital ratio, such as book value of assets, as a proxy for credit risk. Nevertheless, this approach does not distinguish the risk. Consequently, the methodology approach first uses the equity ratio (equity/total assets) as $K$ in the basic model; next, it substitutes it with risk-adjusted measures, i.e., the tier 1 ratio, the total capital ratio and the density of assets:

- tier 1 ratio is the ratio between tier 1 capital and the total risk-weighted assets

- tot_cap_ratio is the ratio between total bank capital and risk-weighted assets

- density is the ratio between risk-weighted assets and total assets.

Commercial banks have higher profitability than the cooperatives ones

Figure 1 ROA for commercial and cooperative over the period 2006-2012 (see online version for colours)

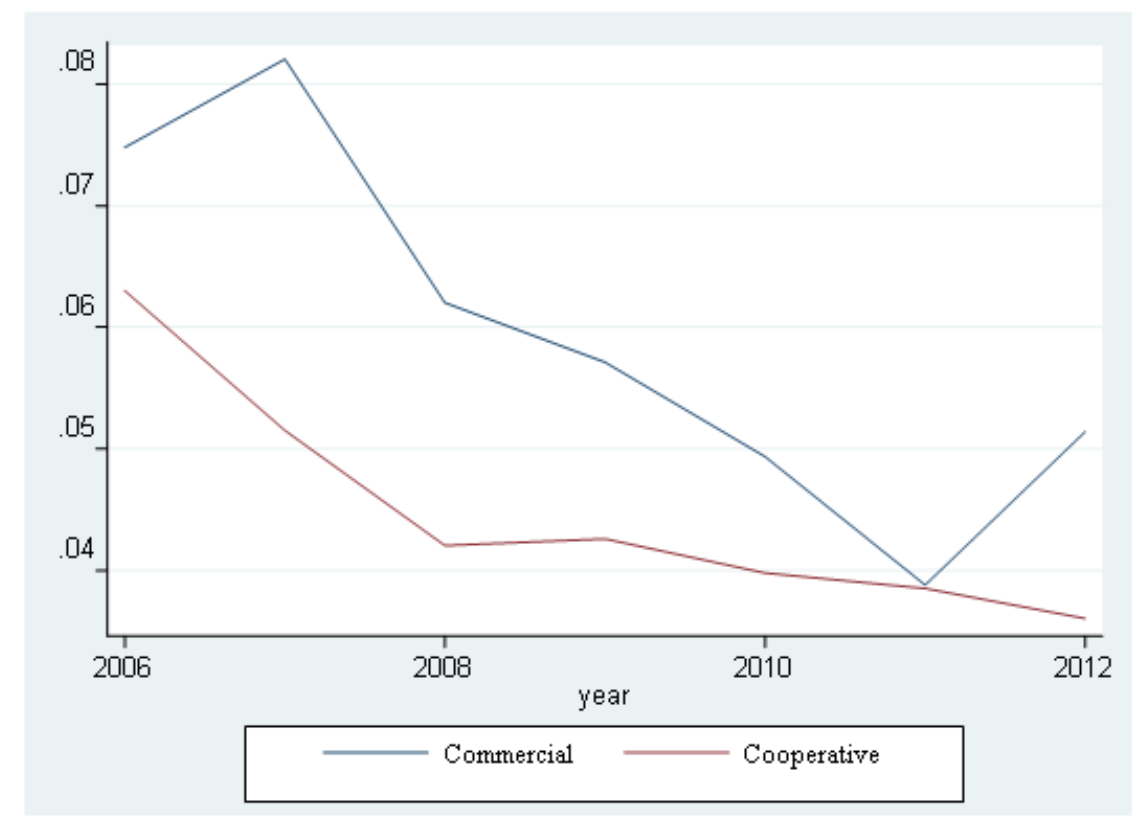

In Table 1, the description of variables is reported.

Table 2 shows the summary statistics of variables for all of the banks of Table 1 .

Next, the same statistics for the subsamples of cooperative and commercial banks are reported. The data are expressed in thousands of Euros.

To mitigate the effect of outliers, the variables loans to deposits (ltd_w) and equity to total assets (etta_w) were winsorised at the $1 \%$ and $99 \%$ levels. 
Table 1 Description of variables

\begin{tabular}{|c|c|c|c|}
\hline Label & Variable & Description & Expected sign \\
\hline Size & Ln (total assets) & $\begin{array}{l}\text { It is the natural logarithm of total } \\
\text { assets at the end of the year. }\end{array}$ & + \\
\hline Dependency & $\begin{array}{l}\text { Deposits and STF/total } \\
\text { assets }\end{array}$ & $\begin{array}{l}\text { It is the ratio between deposits and } \\
\text { short-terms funds and total assets. }\end{array}$ & + \\
\hline Ltd_w & Loans/deposits and STF & $\begin{array}{l}\text { It is the ratio between loans and } \\
\text { deposits and short-terms funds. }\end{array}$ & + \\
\hline Etta_w & Equity/total assets & $\begin{array}{l}\text { It is the ratio between the equity } \\
\text { and total assets. }\end{array}$ & $+1-$ \\
\hline Tier 1 ratio & $\begin{array}{c}\text { Regulatory tier } 1 \\
\text { capital**/risk-weighted } \\
\text { assets* }\end{array}$ & $\begin{array}{l}\text { It is the ratio between the tier } 1 \\
\text { capital and the RWA as reported in } \\
\text { Bankscope. }\end{array}$ & $+1-$ \\
\hline $\begin{array}{l}\text { Total capital } \\
\text { ratio }\end{array}$ & $\begin{array}{c}\text { Total regulatory } \\
\text { capital***/ } \\
\text { risk-weighted assets* }\end{array}$ & $\begin{array}{l}\text { It is the sum of tier } 1 \text { and tier } 2 \\
\text { capital divided by the RWA as } \\
\text { reported in Bankscope. }\end{array}$ & $+1-$ \\
\hline Density & $\begin{array}{l}\text { Risk-weighted } \\
\text { assets/total assets }\end{array}$ & $\begin{array}{l}\text { It is the ratio between RWA and } \\
\text { total assets. }\end{array}$ & $+1-$ \\
\hline
\end{tabular}

Notes: *It is the sum of the assets of bank and off-balance sheet exposure weighted for the risk. The weights depend on the internal rating mechanism adopted, IRB or standard formula following Basel II mechanism. Not directly available in Bankscope.

**Core tier $1+$ hybrid tier 1 . Composed by equity capital (issued and fully paid ordinary shares/common stock and non-cumulative perpetual preferred stock but excluding cumulative preferred stock) and disclosed reserves.

***Tier $1+\operatorname{tier} 2$. It is the sum of tier 1 and tier 2 capital (undisclosed reserves, revaluation reserves, general provisions, hybrid debt capital instruments, subordinated term debt).

Table 1 contains information on the bank-specific characteristics. For each bank specific feature, it reports how the variable (ratio) is constructed and expected effect.

The average results indicate that cooperative banks are dimensionally smaller than commercials banks (12.62 and 13.93, respectively), can rely on more deposits ( 0.80 and 0.72 , respectively) and have slightly less liquidity ( 0.81 and 0.80 , respectively). In this last case, the results are controversial because the median value represent the opposite situation, in fact, commercials have a larger value denoting lower liquidity. A possible explanation derives from the dependency on non-deposit funds, as commercials might hold liquid assets against possible liquidity shocks. These differences across the two bank types are in line with theory and evidence, which find a retail-oriented bank business model in a cooperative environment. Looking at the capital measure, we do not find cooperatives to be better capitalised than commercial banks, as is common in the literature. For instance, the ratio of equity to total assets shows wide-range variation among the two type of bank, commercial and cooperatives (0.106 and 0.084, respectively). Considering the risk-adjusted measure of capital, the variation in the ratio decrease, for instance the average tier 1 ratio is 15.285 for commercial banks and 15.307 for cooperative banks. In addition, the total capital ratio, which consider additional forms of capital, does not indicate relevant differences (15.248 and 16.886, respectively). However, these differences become larger looking at the median value; therefore, they 
warrant further investigation. In addition, it has to be noted that commercials are better capitalised in terms of the capital ratio (equity to total assets), but this finding is no longer observed when the risk-adjusted measure are introduced. Surprisingly, there is no variation among bank types for the risk of overall operations labelled density (of assets) in this paper. Overall, this first partial step of the analysis suggests that there are important differences across bank types in terms of the capital structure reflected in risk-adjusted measures. The differences highlighted by descriptive statistics could derive directly from the business model of the two types of banks and might affect the bank performance differently, especially during financial and economic turmoil.

Table 2 Summary statistics of the sample in the period 2006-2012

\begin{tabular}{|c|c|c|c|c|c|c|}
\hline \multicolumn{7}{|l|}{ Whole sample } \\
\hline Variable & $N$ & Mean & Median & Min & $\operatorname{Max}$ & $S d$ \\
\hline Size & 9,900 & 12.723 & 12.700 & 7.120 & 18.610 & 1.233 \\
\hline Dependency & 9,892 & 0.794 & 0.870 & 0.000 & 1.110 & 0.166 \\
\hline Ltd_w & 9,879 & 0.813 & 0.714 & 0.113 & 2.122 & 0.385 \\
\hline Etta_w & 9,900 & 0.086 & 0.077 & 0.035 & 0.262 & 0.038 \\
\hline Tier 1 ratio & 4,359 & 15.305 & 13.200 & 0.130 & 136.210 & 8.654 \\
\hline Totcapratio & 3,406 & 16.759 & 14.780 & 0.120 & 191.070 & 8.882 \\
\hline Density & 3,824 & 0.007 & 0.007 & 0.001 & 0.737 & 0.012 \\
\hline \multicolumn{7}{|l|}{ Commercials } \\
\hline Variable & $N$ & Mean & Median & Min & $\operatorname{Max}$ & $S d$ \\
\hline Size & 789 & 13.930 & 14.000 & 7.120 & 18.610 & 1.877 \\
\hline Dependency & 783 & 0.725 & 0.800 & 0.000 & 0.980 & 0.215 \\
\hline Ltd_w & 775 & 0.801 & 0.816 & 0.113 & 2.122 & 0.508 \\
\hline Etta_w & 789 & 0.106 & 0.080 & 0.035 & 0.262 & 0.070 \\
\hline Tier 1 ratio & 348 & 15.285 & 11.455 & 3.210 & 119.000 & 14.166 \\
\hline Totcapratio & 264 & 15.248 & 12.240 & 4.470 & 129.260 & 12.870 \\
\hline Density & 305 & 0.006 & 0.006 & 0.001 & 0.013 & 0.002 \\
\hline \multicolumn{7}{|l|}{ Cooperatives } \\
\hline Variable & $N$ & Mean & Median & Min & $\operatorname{Max}$ & $S d$ \\
\hline Size & 9,111 & 12.618 & 12.650 & 7.700 & 17.530 & 1.100 \\
\hline Dependency & 9,109 & 0.800 & 0.870 & 0.000 & 1.110 & 0.159 \\
\hline Ltd_w & 9,104 & 0.814 & 0.713 & 0.113 & 2.122 & 0.373 \\
\hline Etta_w & 9,111 & 0.084 & 0.076 & 0.035 & 0.262 & 0.033 \\
\hline Tier 1 ratio & 4,011 & 15.307 & 13.340 & 0.130 & 136.210 & 8.001 \\
\hline Totcapratio & 3,142 & 16.886 & 14.950 & 0.120 & 191.070 & 8.452 \\
\hline Density & 3,519 & 0.007 & 0.007 & 0.001 & 0.737 & 0.012 \\
\hline
\end{tabular}

Note: This table contains summary statistics for the whole sample, for disentangled sample by commercials and cooperatives of German and Italian banks over the period 2006-2012. 


\section{Econometric design}

\subsection{Empirical model}

The following basic equation estimates the impact of the ownership structure on bank performance for commercials and cooperatives:

$$
y_{i t}=\alpha+\beta_{1} * \operatorname{Size}_{i t}+\beta_{2} * \text { Dependency }_{i t}+\beta_{3} * \operatorname{LTD}_{i t}+\beta_{4}\left(K_{i t}\right)+\varepsilon_{i t},
$$

where $y_{i t}$ is the dependent variable and represents performance measured by ROA as described in Table 1.

\subsection{Independent variables}

The variables used in the model to explain the bank performance are as follows:

- size is the natural logarithm of total assets

- dependency is related to how deposits and short-term funding are important in the collection of funds

- $\quad l t d \_w$ is the ratio of loans to deposits

- $K$ is a vector of alternative measures of bank capital.

Specifically, the model assesses the impact of size (total assets). The banks' dependency on deposits (deposits/total assets, which is dependency) captures the composition of the liabilities; a bank with more deposits will have more stable financing compared to one that relies more on markets. On the asset side, the model considers the so-called 'deposits transformation' activity (loans/deposits, that is ltd_w) on economic performance. This ratio shows the relationship between comparatively illiquid assets (i.e., loans) and comparatively stable funding sources (i.e., deposits and other short-term funding) and is considered a measure of liquidity. In particular, a higher ratio corresponds to lower liquidity. ${ }^{5}$ Among the determinants of bank performance, the strength of capital has a significant and positive role, and the literature often uses the capital ratio, such as book value of assets, as a proxy for credit risk. Nevertheless, it does not distinguish the risk. Consequently, the methodology first uses the equity ratio (equity/total assets) as $K$ in the basic model; next, it substitutes it with risk-adjusted measures: the tier 1 ratio, the total capital ratio and the density of assets:

- tier 1_ratio is the ratio between the tier 1 capital and the total risk-weighted assets

- tot_cap_ratio is the ratio between total bank capital and risk-weighted assets

- density is the ratio between risk-weighted assets and total assets.

To prevent multicollinearity issues, a correlation analysis (Table A3) is performed. The correlation between the dependency and assets is -0.5556 and needs to be further investigated. In performing a variance inflation factor test (VIF) on an OLS regression including temporal and individual effects, the results indicate a moderated correlation that can be safely ignored. 
The random effects (RE) model is most suited in this research design due to the probable effect of idiosyncratic components on performance. In addition, for large ' $N$ ' and fixed small ' $\mathrm{T}$ ' fixed effects (FE), the estimates are inconsistent and may aggravate the problem of multicollinearity (Baltagi, 2005). In addition to being a micro panel, the individual (between) variability is more important than the temporal (within) variability, as suggested by the variance decomposition analysis, where the between effect represent approximately $88 \%$ (see Table A2).

\section{Empirical results}

Moving to the multivariate analysis as specified in equation (1), the results are reported in Table 3 for the basic model containing as the $\mathrm{K}$ measure the capital ratio (equity to total assets). Table 4 contains the results for the alternative capital and risk measures.

\subsection{Basic model}

The results confirm that dimension (i.e., size) has a significant effect on the profitability of German and Italian banks. More specifically, banks respond to an increase of their dimension by reducing $R O A$. On average, the larger a bank (commercial or otherwise) is, the less profitable it is in terms of ROA (see columns Table 3). This result is in line with the findings of Vander Vennet and Mergaerts (2016), who find a negative impact of size on bank performance (in terms of ROE, ROA, NIM and Z-scores) in the short-term. The dependency from funding has no explanatory power in the basic model because the impact is significant and negative only for the explanation of cooperative bank performance when using regulatory ratios (see Table 4). For this reason, the discussion of results is postponed to the next section. The results of ltd_w, which measures liquidity, show the direct relation between a higher figure of ltd (lower liquidity) and higher performance. The effect of the capital ratio is positive for both cooperatives and commercial banks, in line with theories and evidence that better capitalised banks have stronger screening incentives (e.g., Coval and Thakor, 2005) and monitoring incentives (e.g., Mehran and Thakor, 2011), in contrast with the literature which highlights higher capital a potentially increasing bank risk taking.

For this reason, it is also appropriate to consider capital measures that take into account the risk.

\subsection{Alternative $K$ measures}

The high leverage of a bank is often associated with higher ROE, the volatility of economic results and, in general, a higher firm risk. Implicitly, there is an incentive for banks to maintain a high leverage to maximise the returns on equity. However, what occurs for the banks that do not have this primary objective? Are there some differences in the two types of banks? This section analyses the impact of different indicators of the capital structure on bank performance taking into consideration the ownership structure and risk. To this point, this evidence may be further highlighted taking into account how tier 1 and, in general, capital are dealt with in a cooperative 'environment': most of the net income has to be retained in a cooperative bank. 
Table 3 RE regression results for the basic model

\begin{tabular}{lcc}
\hline & Cooperative & Commercial \\
\hline Size & $(1)$ & $(2)$ \\
& ROA & ROA \\
Dependency & $-0.00850^{* * *}$ & $-0.00500^{*}$ \\
& $(-7.82)$ & $(-2.28)$ \\
Ltd_w & 0.00652 & -0.0171 \\
& $(1.84)$ & $(-0.73)$ \\
Etta_w & $0.00511^{* *}$ & 0.00731 \\
& $(2.79)$ & $(0.59)$ \\
cons & $0.0621^{* * *}$ & $0.133^{* * *}$ \\
& $(4.48)$ & $(3.50)$ \\
N & $0.128^{* * *}$ & $0.108 *$ \\
$R$-sq within & $(12.14)$ & $(2.53)$ \\
Between & 9104 & 775 \\
Overall & 0.124 & 0.0557 \\
\hline
\end{tabular}

Notes: This table provides the estimate of bank performance determinants using a sample of German and Italian banks over the 2006-2012 period. The model contains a vector of bank capital, as three different alternatives measure of capital are considered in regression analysis, respectively equity ratio; tier 1 ratio and totcapratio; and a measure of risk, dependency. $t$-statistics in parentheses $* p<0.05, * * p<0.01, * * * p<0.001$.

Deposits have a stable dynamic, and in the last several years, deposits have decreased (see, e.g., monthly bulletin of ECB, 2013). This means that high growth in the leverage level of bank capital has been achieved through the growth of other components of collections, namely, the wholesale interbank market, repurchase agreements (REPO), and the issuance of securities. In this case, the funding structure could be very volatile implying interest risk and liquidity risk that are potentially high. Furthermore, the capital structure is related to the business cycle. In fact, during a recession, the value of assets declines dramatically and with constant debt, leverage increases to the target level. As such, banks start the deleveraging process through different channels (see, e.g., Cohen, 2013) with different macroeconomic implications (see, e.g., Feyen and González Del Mazo, 2013). In addition, what occurs for the banks that cannot use all of these channels? For instance, cooperatives cannot raise capital in the open market and in general, the principles of transferability of shares are very restrictive. Are there differences between the two types of banks?

Therefore, the analysis is replicated using alternative measures of capital (i.e., K), substituting regulatory measures that take into account for risk. The variables used are the tier 1 ratio, a core measure of bank's capital strength; the total capital ratio, which takes into account other component of capital considered supplementary; and the density, 
which measures the average relative risk - according to regulatory criteria - of a bank overall operations (see Table 1). The results are provided in Table 4.

Table 4 RE regression results for the alternatives capital measures

\begin{tabular}{lcccccc}
\hline & Cooperative & Commercial & Cooperative & Commercial & Cooperative & Commercial \\
\hline & $(3)$ & $(4)$ & $(5)$ & $(6)$ & $(7)$ & $(8)$ \\
& $R O A$ & $R O A$ & $R O A$ & $R O A$ & $R O A$ & $R O A$ \\
\hline Size & $-0.00664^{* * *}$ & $-0.00704^{* *}$ & $-0.00877^{* * *}$ & $-0.0105^{* *}$ & $-0.00608^{* * *}$ & -0.00781 \\
& $(-10.56)$ & $(-2.91)$ & $(-11.10)$ & $(-2.67)$ & $(-9.29)$ & $(-1.78)$ \\
Dependency & $-0.0162^{* * *}$ & -0.0134 & $-0.0178^{* * *}$ & -0.0115 & $-0.0150^{* * *}$ & -0.0185 \\
& $(-4.44)$ & $(-0.85)$ & $(-5.46)$ & $(-0.60)$ & $(-3.85)$ & $(-0.89)$ \\
Ltd_w & $-0.00330^{*}$ & -0.00760 & $-0.00478^{* * *}$ & -0.00973 & -0.00275 & -0.0102 \\
& $(-2.53)$ & $(-0.97)$ & $(-3.81)$ & $(-1.08)$ & $(-1.94)$ & $(-1.04)$ \\
Tier 1 ratio & $-0.000126^{*}$ & 0.000240 & & & & \\
& $(-2.14)$ & $(1.43)$ & & & & \\
Totcapratio & & & $-0.000169^{*}$ & 0.000111 & & \\
& & & $(-2.50)$ & $(0.57)$ & & 1.093 \\
Density & & & & $0.0174 *$ & $(1.56)$ \\
& & & & & & \\
cons & $0.135^{* * *}$ & $0.152^{* *}$ & $0.166^{* * *}$ & $0.210^{* *}$ & $0.125 * * *$ & 0.168 \\
& $(11.96)$ & $(3.08)$ & $(12.64)$ & $(2.78)$ & $(10.76)$ & $(1.87)$ \\
\hline N & 4011 & 348 & 3142 & 264 & 3519 & 305 \\
R-sq within & 0.224 & 0.190 & 0.286 & 0.234 & 0.217 & 0.172 \\
Between & 0.0603 & 0.135 & 0.0496 & 0.112 & 0.0597 & 0.113 \\
Overall & 0.0769 & 0.154 & 0.0659 & 0.156 & 0.0689 & 0.151 \\
\hline Notes: & & & & &
\end{tabular}

Notes: This table provides the estimate of bank performance determinants using a sample of German and Italian banks over the 2006-2012 period. The model contains a vector of bank capital, as three different alternatives measure of capital are considered in regression analysis, respectively equity ratio; tier 1 ratio and totcapratio; and a measure of risk, dependency. $t$-statistics in parentheses. $* p<0.05, * * p<0.01, * * * p<0.001$.

The results show two things: first is the opposite sign between the two types of bank considered, and second is that the effect of capital is negative for cooperatives. This finding means that banks that rely more and more on deposits as a source of funding experience worse performance in the cooperative case. In contrast, for commercial banks, the dependency on funding from retail customers does not have an important role in the explanation of performance. Second, the liquidity has a surprisingly reverse impact. Therefore, the direct relation between a higher figure of ltd and performance is not confirmed in this study. In the cooperative case, the results denote a reverse relation between liquidity and returns; higher ltd negatively affects performance. In liquidity management, a difference between two types of bank emerge. In general, cooperatives do not have access to external financing and tend to be more liquid than commercials. 
However, in this case is not possible to explain this effect because they have quite similar mean (median) ratios and this paper does not study the structure of loans and in particular net loans, which could affect the liquidity formation process and in turn performance. Therefore, the controversial results need to be further investigated.

The results of the regressions with regulatory capital ratios and risk measures confirm the suspicion about the effects of the ownership structure, as capital affects the performance of cooperatives and commercials differently. In particular, this is true accounting for the tier 1 ratio and the total capital ratio, which have different signs for cooperatives and commercial banks (negative and positive respectively). For cooperatives, the strength of capital has a negative impact on bank returns, in contrast to commercial banks, for which a capital increase positively affects the dependent variable if it is not significantly different from zero (Table 4). The reason for this difference can be retraced as the absorption of resources for capital building in a cooperative environment. In fact, a part of profits has to be retained and allocated to legal reserves. There are no substantial differences in considering core capital or total capital (risk-adjusted) with hybrid and subordinated forms because the magnitudes of the coefficients are quite similar.

Lastly, looking at the risk of overall operations, the results do not confirm a difference in risk policies (i.e., density) on bank performance accounting for ownership because the coefficients both have positive signs. In addition, if the two types of bank have different profiles, it is less risky for cooperatives. Definitively, the relation of more risk more return is confirmed for both.

The effect of the capital ratio (equity/total assets) on ROA is positive for both types of banks. This result is in line with the literature and numerous studies that demonstrate a positive relationship by attributing it to greater screening and monitoring activities associated with higher levels of capital. However, this is in contrast to the theory that high levels of capital might increase risk taking. Therefore, this work deepens this aspect by introducing capital measures that take risk, the total capital ratio and asset density into account and evaluating the impact on performance taking into account the different structures and capital formations, as well as the different risk profile in the cooperative context.

This analysis has two interesting results: the risk adjusted capital measures has a different impact on the types of banks considered and the negative impact of capital on cooperative bank performance.

These result can be explained by a downsizing of assets, essentially lending activities, and hence a deterioration in operating income for cooperative banks. This argument is also supported by Pfleiderer (2012), who reports the words of Josef Ackerman, CEO of Deutsche Bank, in an interview: "more equity could increase bank stability. At the same time, however, they should restrict their ability to lend to the rest of the economy". In the cooperative context, a reduction in the activity may result in a reduction in the diversification of the portfolio due both to the constraint on territoriality to which the cooperative banks are subjected and to the obligation to offer loans to their members in percentage terms. Cooperative banks are more likely to end up with insufficiently diversified loan portfolios if they are small and constrained to work in geographically delimited areas with low industry diversification (Gobbi, 2005) Such peculiarities may thus further conflict with theories that higher levels of capital are associated with better performance by enhancing screening and monitoring, which is difficult to adapt to the cooperative context. A further argument about the negative relationship between capital 
and performance in the cooperative context lies in the process of training it. An increase in capital in the cooperative context can be essentially done in two ways: first, is to increase profits, which are considered as a percentage reserve requirement, and second is through the subscriptions of new members being foreclosed by the outside market. In the case of a negative economic cycle, such mechanisms are difficult to pursue and activate; however, positive effects may occur in the long run. Finally, a further discriminating factor could be represented by the different risk profile of the two types of banks. However, the analysis of the average riskiness of all operations (density) does not seem to favour this argument. Finally, there is no substantial difference between the use of a measure that takes into account only core capital and one that also takes into account such factors as hybrid and subordinated debt for both types of bank.

In conclusion, the work documented a different effect of the impact of capital, as measured through regulatory measures that take into account the risk between commercial banks and cooperatives, noting that this effect is not captured by the use of the most common relationship, which uses book values. The negative report documented is an expression of a reality where bankers are reluctant to adapt to regulatory capital requirements and continue to handle heavily exploited companies. Capital is undoubtedly an important factor whose benefits, both individual and social, are strongly shared and documented by a plethora of studies, yet it is also a cost, and under that profile it should be more thoroughly studied. Moreover, the cooperative context needs to be further researched, particularly the cooperative model, the peculiarities of which mean that the main conclusions drawn for other types of banks may not adhere perfectly to the examined mutualism model.

In conclusion, the variables that explain bank performance do not have the same effect when accounting for the ownership structure. This finding is particularly notable when we consider capital and liquidity. In fact, in a cooperative environment, capital has a different process of formation and management. Due to the limitation of transferability of shares, cooperatives cannot access the open market to raise capital. Because the external channel is precluded, the cooperatives can push on retained earnings or asset-side strategies to strengthen; moreover, they have also different mechanisms of capital formation and different risk profile, which are derived directly from their mutualism nature. In addition, the liquidity management mechanisms are different because they cannot make use of liquidity in excess if not organised in networks. Therefore, it matters to account for the ownership structure because it affects the business model, which is the gathering of funds and the lending of these funds, the availability of the resources of the first quality to satisfy credit risk absorption. Therefore, the effect of capital on bank performance is not the same for cooperatives and commercials.

\section{Robustness checks}

Turning to an exploration of the robustness of the results, Table 4 shows the results of the regression using the same model with the introduction of an interaction variable $\mathrm{K} * \mathrm{~S}$, where

- $\mathrm{K}$ is the vector of alternative measures of capital

- $\mathrm{S}$ is the dummy of specialisation, which takes a value of 1 if the bank is a cooperative and 0 otherwise. 
This model differentiates in particular the combined effect of capital and ownership not distinguishing the effect of bank type on the other determinants of performance.

Table 5 Random effect regression with interaction variables

\begin{tabular}{|c|c|c|c|c|}
\hline & $\begin{array}{c}(1) \\
R O A\end{array}$ & $\begin{array}{c}(2) \\
R O A\end{array}$ & $\begin{array}{c}(3) \\
R O A\end{array}$ & $\begin{array}{l}(4) \\
R O A\end{array}$ \\
\hline Size & $\begin{array}{c}-0.00686^{* * *} \\
(-7.25)\end{array}$ & $\begin{array}{c}-0.00609 * * * \\
(-9.36)\end{array}$ & $\begin{array}{c}-0.00789 * * * \\
(-9.06)\end{array}$ & $\begin{array}{c}-0.00572 * * * \\
(-8.76)\end{array}$ \\
\hline Dependency & $\begin{array}{c}0.000685 \\
(0.07)\end{array}$ & $\begin{array}{c}-0.0178^{* * *} \\
(-3.89)\end{array}$ & $\begin{array}{c}-0.0194 * * * \\
(-4.13)\end{array}$ & $\begin{array}{c}-0.0171^{* *} \\
(-3.15)\end{array}$ \\
\hline Ltd_w & $\begin{array}{c}0.00468 \\
(1.10)\end{array}$ & $\begin{array}{c}-0.00408^{*} \\
(-2.28)\end{array}$ & $\begin{array}{c}-0.00547 * * \\
(-2.85)\end{array}$ & $\begin{array}{c}-0.00381 \\
(-1.77)\end{array}$ \\
\hline Etta_w & $\begin{array}{c}0.157 * * * \\
(5.21)\end{array}$ & & & \\
\hline Ettainter & $\begin{array}{c}-0.109 * * \\
(-3.23)\end{array}$ & & & \\
\hline Tier 1 ratio & & $\begin{array}{c}0.000303 \\
(1.64)\end{array}$ & & \\
\hline Tier $1 \times$ specialisation & & $\begin{array}{c}-0.000459^{*} \\
(-2.25)\end{array}$ & & \\
\hline Totcapratio & & & $\begin{array}{c}0.000262 \\
(1.19)\end{array}$ & \\
\hline Totcapratio $\times$ specialisation & & & $\begin{array}{c}-0.000460 \\
(-1.93)\end{array}$ & \\
\hline Density & & & & $\begin{array}{c}1.681 * * * \\
(6.62)\end{array}$ \\
\hline Density $\times$ specialisation & & & & $\begin{array}{c}-1.663^{* * *} \\
(-6.56)\end{array}$ \\
\hline _cons & $\begin{array}{c}0.114 * * * \\
(7.17)\end{array}$ & $\begin{array}{c}0.131 * * * \\
(10.25)\end{array}$ & $\begin{array}{c}0.158 * * * \\
(10.01)\end{array}$ & $\begin{array}{c}0.123 * * * \\
(9.12)\end{array}$ \\
\hline $\mathrm{N}$ & 9879 & 4359 & 3406 & 3824 \\
\hline $\mathrm{R} 2 \_\mathrm{w}$ & 0.0816 & 0.193 & 0.242 & 0.182 \\
\hline R2_b & 0.0929 & 0.0725 & 0.0528 & 0.0719 \\
\hline R2_o & 0.0910 & 0.0899 & 0.0675 & 0.0857 \\
\hline
\end{tabular}

Note: The table contains regression results for RE model with interaction variable instead of regression performed on subsamples of commercials and cooperatives bank.

The results are similar to a previous finding. The effect of $K$ on performance is different controlling for the cross-effect between $K$ and S (i.e., $K * S$ ). In particular, the effect becomes negative for cooperatives (it occurs in column 2 of Table 4). In other words, the ownership structure drives performance and the impact of capital on it. The impact of 
capital on performance is moderated by the ownership structure, which means that in general, banks with a higher 'capital cushion' do better than others, but in particular, this is no longer true if the bank is a cooperative and if we consider risk-adjusted capital measures. In other words, being a cooperative bank affects the process of income production through some inefficiencies (documented by dependency and ltd_w), as well as the process of capital building, through some capital constraints (shown by $K$ ), and thus economic performance.

\section{Conclusions}

Using a double panel of Italian and German banks over the period of 2006 to 2012, the paper investigates the impact of capital on performance in cooperative and commercial environments. The primary contribution moves in several directions because it is one of few studies both dealing with the relation between bank performance and ownership structure and introducing in the model a country effect using a two-country approach. Further, for the first time, to the best of my knowledge, the impact of capital structure on bank performance is analysed considering different institutional ownership structures.

Even if the sample is largely composed of small-sized cooperative banks, the mean values of variables are strongly influenced by commercial banks, larger than cooperative ones.

The results show a non-optimal picture for cooperative banks: in fact, being a cooperative does not have a positive impact on performance measured by ROA as they perform worse than commercial banks. The performance is explained by a set of variables that reflect a bank's core business and highlight differences in the business models. These differences are particularly pronounced when we consider capital measures and liquidity driven by the ownership structure. In fact, in a cooperative environment, capital has a different process of building up and management. The principles of mutualism and cooperation limit the negotiability of shares and, consequently, cooperative banks cannot access the open market to raise capital or to manage liquidity in excess. During negative economic cycles, the possibility to boost retained earnings is limited; therefore, cooperatives will face difficulties in reinforcing capital. In addition, asset strategies cannot be easily pursued. Therefore, accounting for the ownership structure is important because it affects the business model. No differences emerge in the risk policies because the effect is the same on performance for all banks, confirming the positive relation between risk and return. In this model, regulatory risk-adjusted capital measures have more explanatory power compared to the book value.

The findings have important implications for policy makers, academics, researchers and regulators, since the ownership structure has to be considered to estimate bank performance and it drives the effect of capital, suggesting different policies of capital management. Hence, it is important for regulators and supervisors to understand how capital-tightening measures (for instance, Basel III and CRD IV) can affect the performance of different types of banks, considering that the differences in the ownership structure could also determine a limited set of instruments to react to new discipline.

The analysis should be completed considering deeper the liquidity process and the loans dynamics. 


\section{References}

Adams, R. and Mehran, H. (2003) 'Is corporate governance different for bank holding companies?', Federal Reserve Bank of New York Economic Policy Review, April, Vol. 9, No. 1, pp.123-142.

Altunbas, Y., Evans, L. and Molyneux, P. (2001) 'Bank ownership and efficiency', Journal of Money, Credit and Banking, Vol. 33, No. 4, pp.926-954.

Ayadi, R., Llewellyn, D.T., Schmidt, R.H., Arbak, E. and De Groen, W.P. (2010) Investigating Diversity in the Banking Sector in Europe: Key Development, Performance and Role of Cooperative Banks, Centre for European Policy Studies, No. 28, Brussels.

Baltagi, B.H. (2005) Econometric Analysis of Panel Data, 3rd ed., John Wiley \& Sons, Hoboken, NJ.

Beltratti, A. and Stulz, R.M. (2009) 'Why did some banks perform better during the credit crisis? A cross-country study of the impact of governance and regulation', Journal of Financial Economics, 2012, Vol. 105, pp.1-17.

Berger, A. and Bouwman, C. (2009) 'Bank liquidity creation', Rev. Financ. Stud., Vol. 22, No. 9, pp.3779-3837.

Berger, A. and Bouwman, C. (2013) 'How does capital affect bank performance during financial crises?', J. Financ. Econ., Vol. 109, No. 1, pp.146-176.

Berger, A. and Udell, G. (1995) 'Relationship lending and lines of credit in small firm finance', Journal of Business, Vol. 68, No. 3, pp.351-382.

Bülbül, D., Schmidt, R.H. and Schüwer, U. (2013) Savings Banks and Cooperative Banks in Europe, White Paper Series No. 5, SAFE, Frankfurt.

Cihák, M. and Hesse, H. (2007) Cooperative Banks and Financial Stability, IMF Working Papers, No. WP/07/02, SSRN, International Monetary Fund, Washington, DC.

Cohen, B.H. (2013) 'How have banks adjusted to higher capital requirements', BIS Quarterly Review, September, Vol. 2013, No. 2013, pp.25-41.

Coval, J. and Thakor, A. (2005) 'Financial intermediation as a beliefs-bridge between optimists and pessimists', Journal of Financial Economics, Vol. 75, No. 3, pp.535-569.

Demirgüç-Kunt, A. and Huizinga, H. (2010) 'Bank activity and funding strategies: the impact on risk and return', Journal of Financial Economics, Vol. 98, No. 3, pp.626-650.

Di Salvo, R. (2002) 'La «governance» des systèmes bancaires mutualistes et coopératifs en Europe', Revue d'Economie Financière, Vol. 67, No. 3, pp.165-180.

Diamond, D.W. and Rajan, R.G. (2001) 'Liquidity risk, liquidity creation, and financial fragility: a theory of banking', Journal of Political Economy, Vol. 109, No. 2, pp.287-327.

Esty, B.C. (1997) 'A case study of organizational form and risk shifting in the savings and loan industry', Journal of Financial Economics, Vol. 44, No. 1, pp.57-76.

European Central Bank (ECB) (2013) Monthly Bulletin, January, Brussel.

Ferri, G., Kalmi, P. and Kerola, E. (2015) 'Organizational structure and performance in European banks: a reassessment', in Kauhanen, A. (Ed.): Advances in the Economic Analysis of Participatory \& Labor-Managed, Vol. 16, pp.109-141, Emerald Group Publishing Limited, UK.

Feyen, E. and González Del Mazo, I. (2013) European Bank Deleveraging and Global Credit Conditions: Implication of a Multi-year Process on Long-Term Finance and Beyond, Policy Research Working Paper, 6388, The World Bank.

Fonteyne, W. (2007) Cooperative Banks in Europe - Policy Issues, Working Papers, July, pp.1-68, IMF, Washington.

Gobbi, G. (2005) 'Il ruolo della banca locale nel finanziamento delle imprese', in La crisi Dell'impresa Nelle Reti e Nei Gruppi, Cedam, Padova.

Groeneveld, J.M. and Llewellyn, D.T. (2011) Corporate Governance in Cooperative Banks, Working Paper, Rabobank Nederland, Utrecht, the Netherlands. 
Iannotta, G. (2006) 'Testing for opaqueness in the European banking industry: evidence from bond credit ratings', Journal of Financial Services Research, Vol. 30, No. 3, p.287.

Iannotta, G., Nocera, G. and Sironi, A. (2007) 'Ownership structure, risk and performance in the European banking industry', Journal of Banking \& Finance, Vol. 31, No. 7, pp.2127-2149.

Karafolas, S. (2016) Credit Cooperative Institutions in European Countries, Springer.

Koehn, M. and Santomero, A.M. (1980) 'Relation of bank capital and portfolio risk', Journal of Finance, Vol. 35, No. 5, pp.1235-1244.

Mehran, H. and Thakor, A.V. (2011) 'Bank capital and value in the cross-section', Review of Financial Studies, Vol. 24, No. 4, pp.1019-1067.

Mester, L.J. (1993) 'Efficiency in the savings and loan industry', Journal of Banking and Finance, Vol. 17, Nos. 2-3, pp.267-286.

Pfleiderer, P. (2012) 'Reducing the fragility of the financial sector: the importance of equity and why it is not expensive', Presented at Norges Bank Macroprudent Workshop, Oslo.

Stefancic, M. and Kathitziotis, N. (2011) 'An evaluation of Italian Banks in the period of financial distress', International Business \& Economics Research Journal, Vol. 10, No. 10, pp.103-114.

Tahkor, A. (2014) 'Bank capital and financial stability: an economic trade-off or a Faustian bargain?', Annu. Rev. Financ. Econ., Vol. 6, No. 1, pp.185-223.

Valnek, T. (1999) 'The comparative performance of mutual building societies and stock retail banks', Journal of Banking \& Finance, Vol. 23, No. 6, pp.925-938.

Vander Vennet, R. and Mergaerts, F. (2016) 'Business models and bank performance: a long-term perspective', Journal of Financial Stability, Vol. 22, No. C, pp.57-75.

Westman, H. (2009) Comparison of Profitability and Risk in Commercial, Savings and Cooperative Banks, SSRN [online] http://ssrn.com/abstract=1435085 and http://dx.doi.org/ $10.2139 /$ ssrn. 1435085 .

\section{Notes}

1 They account for ROA and ROE as measures of performance and profitability.

2 The countries analysed are Austria, Finland, France, Germany, Italy, Netherlands, and Spain.

3 The data were downloaded on 20 February 2014 by Bankscope Bureau van Dijk.

4 The inclusion of the country effect in the model has been considered and tested, but the results led to non-inclusion.

5 The inclusion of the country effect in the model has been considered and tested, but the results led to non-inclusion.

\section{Appendix}

Table A1 Distribution of sample by country and specialisation

\begin{tabular}{lccc}
\hline & Italy & Germany & Total \\
\hline Commercial & 41 & 73 & 114 \\
Cooperative & 379 & 926 & 1,305 \\
\hline Total & 420 & 999 & 1,419 \\
\hline
\end{tabular}


Table A2 Variance decomposition analysis of total variation of ROA

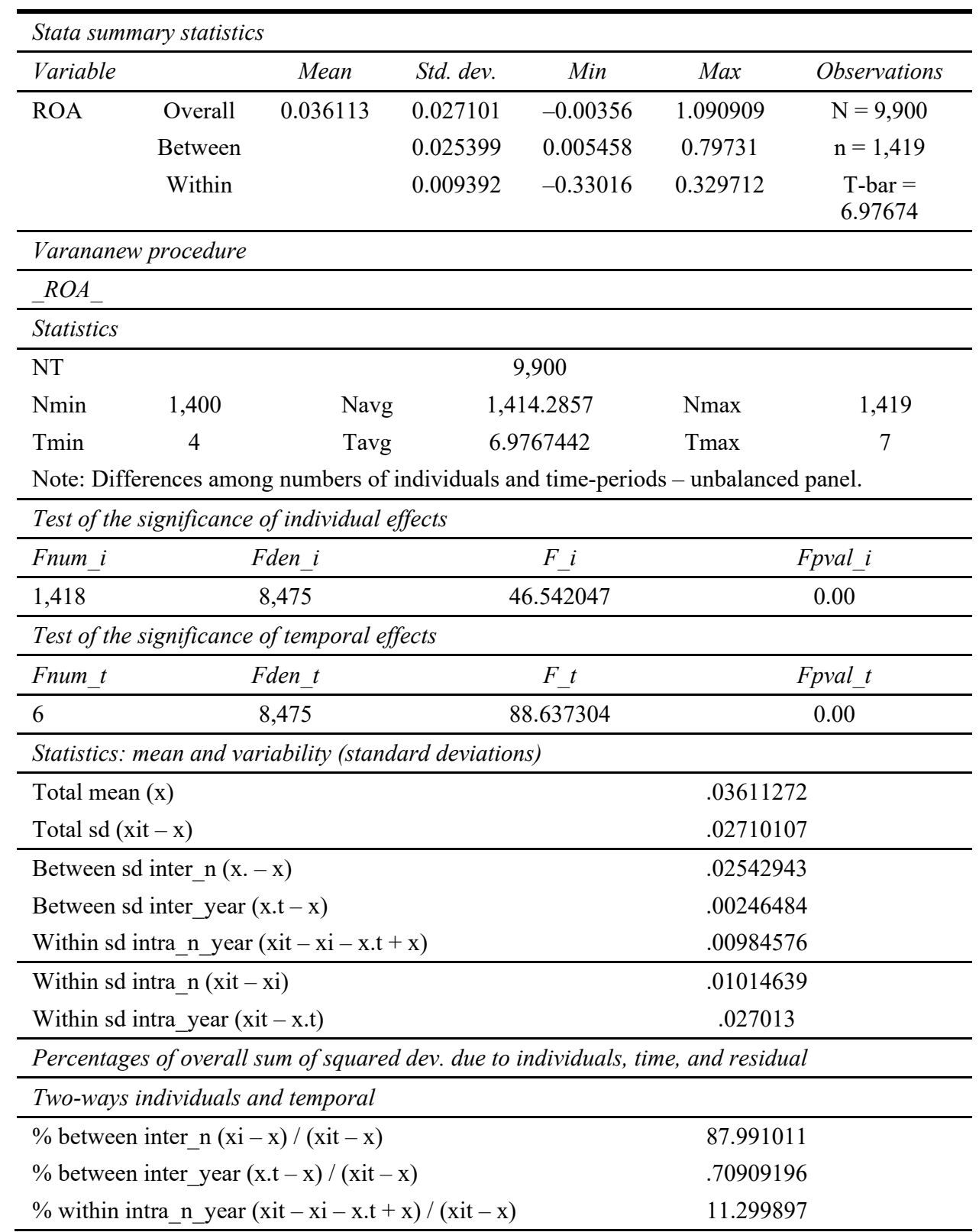

Notes: The table contain s estimation results of summary statistics for the ROA variable performed with stata command xtsum which compute wrongly the degree of freedom when calculating the within deviation. For this reason, is performed also the varananew procedure which gives correct within standard deviation and additional information. 
Table A2 Variance decomposition analysis of total variation of ROA (continued)

\begin{tabular}{|c|c|}
\hline \multicolumn{2}{|l|}{ Focus on one-way individuals: intra_n+ inter_n } \\
\hline$\%$ within intra_n $(x i t-x i) /(x i t-x)$ & 12.008989 \\
\hline Of which explained by between inter_year $(\%)(x . t-x) /(x i t-x i)$ & 5.9046766 \\
\hline \multicolumn{2}{|l|}{ Focus on one-way temporal: intra_year + inter_year } \\
\hline$\%$ within intra_year $(x i t-x . t) /(x i t-x)$ & 99.290908 \\
\hline Of which explained by between inter_n $(\%)(x i-x) /(x i t-x . t)$ & 88.619404 \\
\hline \multicolumn{2}{|l|}{ Fractions of variance due to individuals, time, and residual } \\
\hline \multicolumn{2}{|l|}{ Two-ways individuals and temporal } \\
\hline$\%$ between var inter_n $=$ & 86.258695 \\
\hline$\%$ between var inter_year $=$ & .81041555 \\
\hline$\%$ within var intra_n_year $=$ & 12.930889 \\
\hline \multicolumn{2}{|l|}{ Sum of squared deviations } \\
\hline $\mathrm{TSS}=$ & 7.2704967 \\
\hline BSS_n $=$ & 6.3973836 \\
\hline BSS_year $=$ & .05155451 \\
\hline WSS_n_year $=$ & .82155864 \\
\hline WSS_n $=$ & .87311314 \\
\hline WSS_year $=$ & 7.2189422 \\
\hline Check TSS $=$ BSS_n + WSS_n $=$ & 7.2704967 \\
\hline Check TSS $=$ BSS_year + WSS_year $=$ & 7.2704967 \\
\hline Check TSS $=$ BSS_n + BSS_year + WSS_n_year $=$ & 7.2704967 \\
\hline \multicolumn{2}{|l|}{ Checks } \\
\hline Between sd inter_n from xtreg be $=$ & .0253994 \\
\hline Between sd inter_n from xtreg be wls $=$ & .02542943 \\
\hline Between sd inter_n from xtreg fe two-ways $=$ & .02540027 \\
\hline Between sd inter_year from xtreg be $=$ & .00245631 \\
\hline Between sd inter_year from xtreg be wls $=$ & .00245843 \\
\hline Within sd intra_year from xtreg fe $=$ & .0270135 \\
\hline
\end{tabular}

Notes: The table contain s estimation results of summary statistics for the ROA variable performed with stata command xtsum which compute wrongly the degree of freedom when calculating the within deviation. For this reason, is performed also the varananew procedure which gives correct within standard deviation and additional information. 
Table A3 Matrix-pairwise correlation and significance

\begin{tabular}{lccccccc}
\hline & Size & Dependency & Ltd & Etotassets & $\begin{array}{c}\text { Tier 1 } \\
\text { ratio }\end{array}$ & Totcapratio Density \\
\hline Size & 1 & & & & & \\
Dependency & -0.0146 & 1 & & & & \\
& 0.146 & & & & & \\
Ltd & -0.0028 & -0.1192 & 1 & & & \\
& 0.7787 & 0 & & & & \\
Etotassets & -0.246 & -0.5556 & 0.2048 & 1 & & \\
& 0 & 0 & 0 & & & \\
Tier 1 ratio & -0.2737 & -0.16 & -0.0891 & 0.7092 & 1 & \\
& 0 & 0 & 0 & 0 & & \\
Totcapratio & -0.2817 & 0.0886 & -0.293 & 0.5333 & 0.901 & 1 \\
& 0 & 0 & 0 & 0 & 0 & \\
Density & -0.0192 & -0.0703 & 0.0826 & 0.0328 & -0.0737 & -0.0917 & 1 \\
& 0.2342 & 0 & 0 & 0.0427 & 0 & 0 & \\
\hline
\end{tabular}

